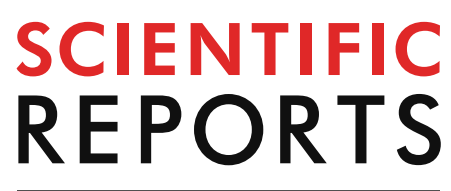

natureresearch

Check for updates

\title{
Effect of elicitors on holm oak somatic embryo development and efficacy inducing tolerance to Phytophthora cinnamomi
}

\begin{abstract}
M. Morcillo ${ }^{1}$, E. Sales ${ }^{2}$, L. Ponce ${ }^{1}$, A. Guillén ${ }^{1}$, J. Segura ${ }^{1}$ \& I. Arrillaga ${ }^{1 \bowtie}$
Holm oak trees (Quercus ilex L.) mortality is increasing worryingly in the Mediterranean area in the last years. To a large degree this mortality is caused by the oomycete Phytophthora spp., which is responsible for forest decline and dieback in evergreen oak forest areas of the southwestern Iberian Peninsula. This study is based on the possibility of applying chemical elicitors or filtered oomycete extracts to holm oak somatic embryos (SE) in order to induce epigenetic memory, priming, that may increase tolerance to the pathogen in future infections. To this end, we first examined the effect of priming treatments on SE development and its oxidative stress state, to avoid elicitors that may cause damage to embryogenic tissues. Both, the sterile oomycete extracts and the chemical elicitor methyl jasmonate (MeJA) did not produce any detrimental effect on SE growth and development, unlike the elicitors benzothiadiazole (BTH) and $p$-aminobenzoic acid (PABA) that reduced the relative weight gain and resulted in necrotic and deformed SE when were applied at high concentrations ( $25 \mu \mathrm{M}$ BTH or $50 \mu \mathrm{M}$ PABA) in accordance with their high malondialdehyde content. No significant differences among elicitation treatments were found in dual culture bioassays, although those SEs elicited with $50 \mu \mathrm{M} \mathrm{MeJA}$ increased $\mathrm{H}_{2} \mathrm{O}_{2}$ production after challenged against active oomycete indicating the activation of stress response. Since this elicitation treatment did not produce any adverse effect in the embryogenic process we suggest that could be used in further priming experiments to produce holm oak plants adapted to biotic stress.
\end{abstract}

Holm oak (Quercus ilex L.) is one of the most representative evergreen species in natural forest ecosystems of the Mediterranean Basin ${ }^{1}$, covering in Spain around 3 million hectares ${ }^{2}$. This tree species along with cork oak (Q. suber L.) dominates the landscape in the agrosilvo pastoral systems (ASPS), called the dehesa in Spain and montado in Portugal. These ASPS support a diversity of ecosystems services, such as biodiversity, regulation of air and water quality, contribution to soil formation and protection from erosion, and climate change regulation by carbon sequestration ${ }^{3,4}$. In addition, both species are of great economical value, since these trees are sources of cork and acorns, being involved in Iberian pigs extensively raising and also in truffle production from natural woodlands and orchards. These facts could improve rural development, and consequently, allow the stabilization of population in depressed areas ${ }^{5-7}$. These ecosystems also have a great landscape, historical and cultural value ${ }^{8}$, being part of the Special Areas of Conservation defined in EU Council Directive 92/43/EEC.

Holm and cork oaks decline has occurred in the Mediterranean basin since the beginning of the XX century, but mortality of oaks in dehesas has increased from the 80's onwards. By that time, the soil borne root oomycete Phytophthora cinnamomi was often recovered from declining stands, so currently, it is considered the main causal factor associated with this syndrome ${ }^{9-11}$. The beginning of infection requires warm and wet soils, in which $P$. cinnamomi affects the fine feeder roots, while lesions extend to major roots in deeper attacks, and finally the oomycete mycelia can collapse the plant vascular system. The progress of the disease courses with tree symptomatology that includes partial or total leaves desiccation ${ }^{9,11}$. Nowadays, the effects of climate change with increasing periods of drought stress aggravate the pathology caused by Phytophthora cinnamomi, and survival is becoming a challenge for the dehesa ${ }^{12}$. In this context and besides prevention and restoration programs, new methods of

${ }^{1}$ ISIC/ERI BIOTECMED, Departamento Biología Vegetal, Universidad de Valencia, Avda Vicent Andrés Estellés s/n, 46100 Burjassot Valencia, Spain. ${ }^{2}$ Departamento de Ciencias Agrarias y del Medio Natural, Escuela Politécnica Superior, Universidad de Zaragoza, Ctra Cuarte s/n, 22071 Huesca, Spain. ${ }^{\circledR}$ email: isabel.arrillaga@uv.es 
forest protection have to be implemented ${ }^{13}$. Conventional breeding programs to obtain disease tolerant/resistant plants have been scarce probably because traditional propagation is extremely difficult for the species mainly due to the poor rooting ability of cuttings, which is also reduced with the aging of parent plants ${ }^{14}$. Recently, a holm- and cork-oaks genetic improvement program to alleviate the "seca" syndrome has been launched by the Spanish Government (National Rural Development Program 2014-2020) cofunded by the European Agricultural Fund for Rural Development (EAFRD). Biotechnological tools allowing clonal propagation of selected resistant genotypes such as axillary budding ${ }^{15}$ or somatic embryogenesis ${ }^{14,16-18}$ are available, although acclimazation of generated plants needs to be improved; also, the induction of systemic resistance, triggering natural plant defenses by the use of elicitors, may offer complementary strategies to breeding programs developed to obtain resilient plant material.

Plants respond to oomycete infection by multiple defense mechanisms, including strengthening of physical barriers, production of antimicrobial molecules, and programmed cell death ${ }^{19}$. In addition, many biological and chemical elicitors, such as necrotizing pathogens, salicylic acid (SA), benzothiadiazole (BTH), and methyl jasmonate (MeJA), have been reported to activate plant immune response to pathogens ${ }^{20-23}$. These elicitors cause the induction of a primed state of enhanced defenses which allows plants to display either faster, stronger, or both, activation of the defense responses after further attacks by pathogens or insects, and also under abiotic stress conditions ${ }^{24}$. Thus, exogenous applications of SA and carvacrol to Ulmus minor successfully enhanced the resistance of trees to the fungal pathogen Ophiostoma novo-ulmi $i^{25,26}$. Also, foliar sprays of SA or BTH to Pinus radiata significantly decreased plant infections by Diplodia pinea ${ }^{27}$ or by Phytophthora cinnamomi ${ }^{28}$. Primed plants present changes at the physiological, molecular, and epigenetic levels that can occur within seconds or hours after stimulation; these changes can be transient or maintained for its lifetime, and can even be inherited by subsequent generation ${ }^{29}$. The most common molecular mechanisms by which a plant is primed involve chromatin modifications, either DNA methylation, histones changes or posttranscriptional variations, which are the basis of inheritable regulation in the expression and gene function that does not involve DNA sequence alterations but epigenetic variations ${ }^{30}$. There are some evidences that biotic stresses exerted on mother plants by herbivores or pathogens can induce transgenerational defenses in progeny when challenging environmental harshness ${ }^{31,32}$. However, most studies of transgenerational induction of defenses to pests and pathogens in plants have focused on short-lived annuals. As an example, applications of $\beta$-amino-butyric acid (BABA) as well as virulent or avirulent strains of Pseudomonas syringae pv. tomato to arabidopsis plants displayed enhanced disease resistance in their progenies when were infected with this phytopathogenic bacteria or with the biotrophic oomycete Hyaloperonospora arabidopsidis ${ }^{33,34}$. However, it remains largely unknown whether this type of transgenerational plasticity also occurs in long-lived forest trees ${ }^{31}$. Environmental maternal effects on the tolerance of Pinus pinaster to biotic stress have been reported ${ }^{32}$. In addition, a recent work ${ }^{35}$, demonstrated that chestnut (Castanea sativa) seedlings of ink-diseased mother trees showed increased tolerance to P. cinnamomi; interestingly, this tolerance was not mediated by seed size, but probably as a consequence of seed priming during fruit development. These inheritable variations could open doors for obtaining resistant or tolerant oak genotypes, which would be included in a recovery program in damaged areas, avoiding oak woodlands and dehesa dieback.

Since somatic embryo (SE) development mimics zygotic embryogenesis, we hypothesize that priming SEs during the proliferation phase may induce transgenerational defense mechanisms that would produce resistance to $P$. cinnamomi in subsequent infections. It is of practical interest to determine first if elicitor molecules released during the early stages of the plant-pathogen interaction could be directly applied to embryogenic lines without altering their development, and second, whether these elicitors may activate priming signals in order to suppress the deleterious effects of fungal diseases in plants. Because of this, the objectives of this work were to assay the effect of some elicitors on holm oak SE development, and to study the preliminary responses of elicited SEs after infection with $P$. cinnamomi.

\section{Results}

Effect of Phytophthora filtered extract (PFE) and chemical elicitors on holm oak SE growth and development. The transference of elicited material to proliferation medium produced secondary embryogenesis and some of the globular embryos underwent maturation up to the early cotyledonary stage. Some elicited-SEs turned necrotic and therefore were subtracted from total well-formed embryos.

After 60 days of elicitation significant differences in SE growth $(p<0.001)$ among elicitation treatments were found. Fresh weight increase was higher on globular SE elicited with MeJA at 5, 10 or $25 \mu \mathrm{M}$, as well as for those elicited with 5 or $10 \mu \mathrm{M}$ BTH, but reduced on those SEs elicited with $25 \mu \mathrm{M}$ BTH (Fig. 1a). However, SE growth rates achieved in these treatments did not significantly differ to that of controls $(2.4 \pm 0.9 \mathrm{~g})$, although on average, we observed higher growth rate for MeJA-elicited SEs $(2.7 \pm 0.6 \mathrm{~g})$ as compared to BTH and PABA treatments (means $1.9 \pm 0.8$ and $1.9 \pm 0.6 \mathrm{~g}$, respectively, Fig. 1a) and these differences were statistically significant $(p=0.01)$. Growth rate of PFE-elicited SEs was on average similar to that of non-elicited embryogenic material $(2.3 \pm 0.7$ g, Fig. 1a).

The analysis of variance showed significant differences on holm oak somatic embryo development among the 14 elicitation treatments tested $(p<0.001$, Fig. 1b). On average, PABA-elicitation treatments significantly reduced the percentage of well-developed embryos as compared to controls $(40.2 \pm 19.1 \%$ vs. $72.5 \pm 7.8 \%, p=0.047)$, particularly at the highest concentration $(50 \mu \mathrm{M})$. This detrimental effect was also observed for BTH-elicitation treatments at 25 and $50 \mu \mathrm{M}$. In contrast, PFE-elicited embryogenic material produced, on average, similar rates of well-developed SEs $(57.4 \pm 13.0 \%)$ to that of controls, as occurred with MeJA treatments $(47.7 \pm 16.0 \%)$. These results would indicate a more detrimental effect on holm oak SEs development of BTH and PABA elicitation treatments, especially when higher concentrations of these compounds are used, as compared to application of MeJA or PFE. 

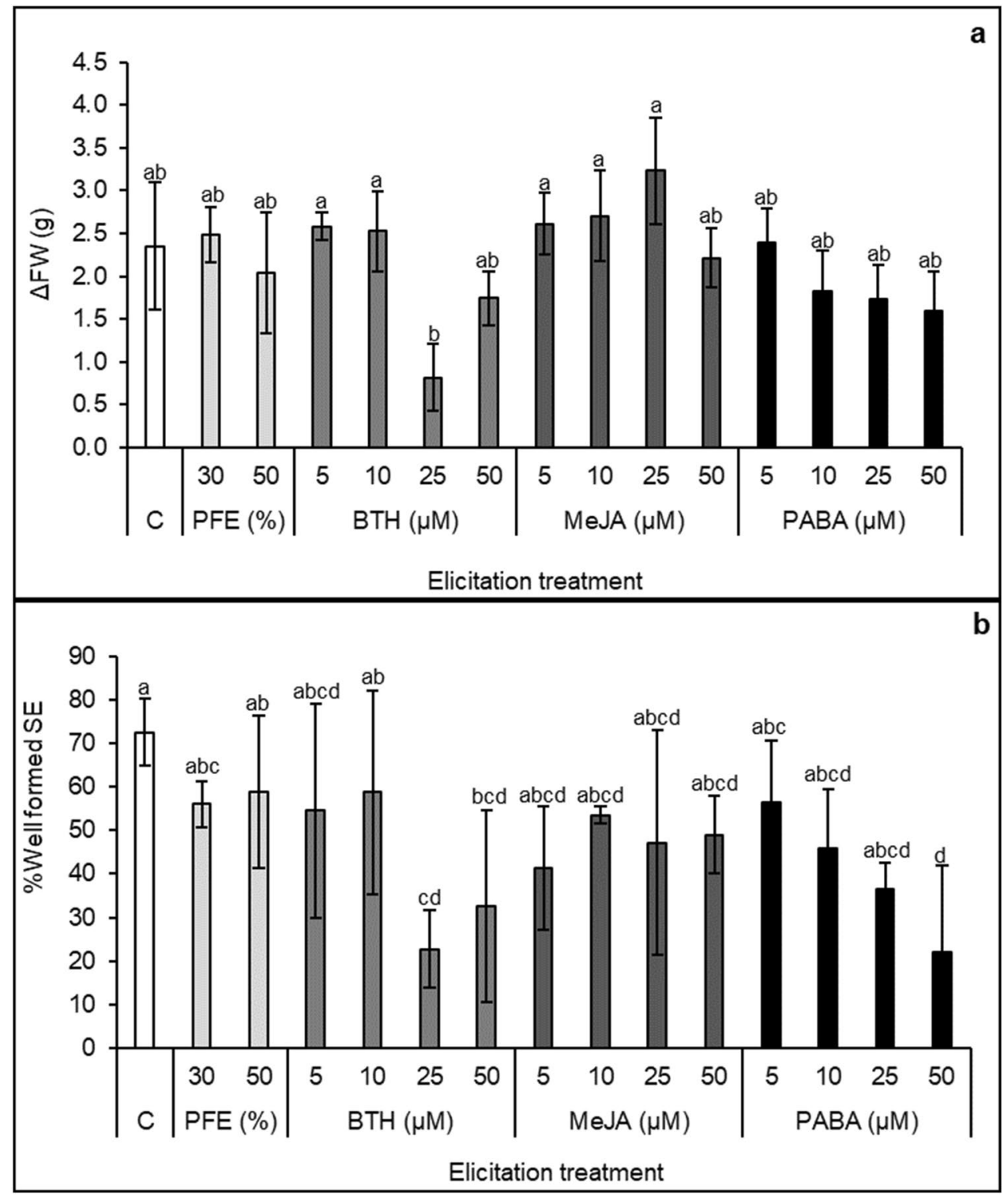

Figure 1. Effect of Phytophthora Filtered Extract, PFE, diluted at 30 or $50 \%$ and benzothiadiazole (BTH), methyl jasmonate (MeJA) and $p$-aminobenzoic acid (PABA) at 5, 10, 25 and $50 \mu \mathrm{M}$, on holm oak somatic embryo development on (a) increment of fresh weight; and (b) percentage of well-developed embryos. C (control treatment). Data are mean \pm SD of three replicates. In (a) values followed by the same letter were not different according to Tukey-B test.

Effect of elicitation treatments on MDA content of holm oak SEs. Irrespective of the elicitation treatment (biological or chemical), levels of MDA in holm oak SEs slightly increased 7d after elicitation (Fig. 2). Nevertheless, analysis performed by Kruskal-Wallis non-parametric test found significant differences only for SEs elicited with PABA at $5 \mu \mathrm{M}$, where MDA content increased from $0.124 \pm 0.042 \mathrm{nmol} \mathrm{g}^{-1} \mathrm{FW}$ in non-elicited material to $0.413 \pm 0.038 \mathrm{nmol} \mathrm{g}^{-1} \mathrm{FW}$, while treatments at the highest BTH and PABA concentration $(50 \mu \mathrm{M})$, showed the lower MDA levels $\left(0.115 \pm 0.033\right.$ and $0.120 \pm 0.005 \mathrm{nmol} \mathrm{g}^{-1} \mathrm{FW}$, respectively). Note that 30 days after elicitation, MDA levels had recovered in SEs elicited with $5 \mu \mathrm{M}$ PABA $\left(0.206 \pm 0.017 \mathrm{nmol} \mathrm{g}^{-1} \mathrm{FW}\right.$, which are closer to $0.129 \pm 0.004 \mathrm{nmol} \mathrm{g}^{-1} \mathrm{FW}$ in controls), but increased in those elicited with $25 \mu \mathrm{M}$ or $50 \mu \mathrm{M}$ PABA (from $0.219 \pm 0.044$ to $0.501 \pm 0.046 \mathrm{nmol} \mathrm{g}^{-1} \mathrm{FW}$ and from $0.120 \pm 0.005$ to $0.279 \pm 0.044 \mathrm{nmol} \mathrm{g}^{-1} \mathrm{FW}$, respectively, Fig. 2). The high MDA content observed in SEs elicited with $25 \mu \mathrm{M}$ PABA $30 \mathrm{~d}$ after the treatment contrasted to the lower levels detected in SEs elicited with either the oomycete extract PFE-50 $\left(0.109 \pm 0.020 \mathrm{nmol} \mathrm{g}^{-1} \mathrm{FW}\right)$ or $10 \mu \mathrm{M}$ BTH $\left(0.112 \pm 0.024 \mathrm{nmol} \mathrm{g}^{-1} \mathrm{FW}\right)$.

Phytophthora cinnamomi growth in dual cultures with elicited holm oak SEs. When Phytophthora cinnamomi mycelia were inoculated in plates containing control and elicited holm oak globular SEs, similar hyphae growth rates were observed towards both types of material, (ratios $r_{\text {control }} / r_{\text {elicited }}$ around 1 ). As it is 


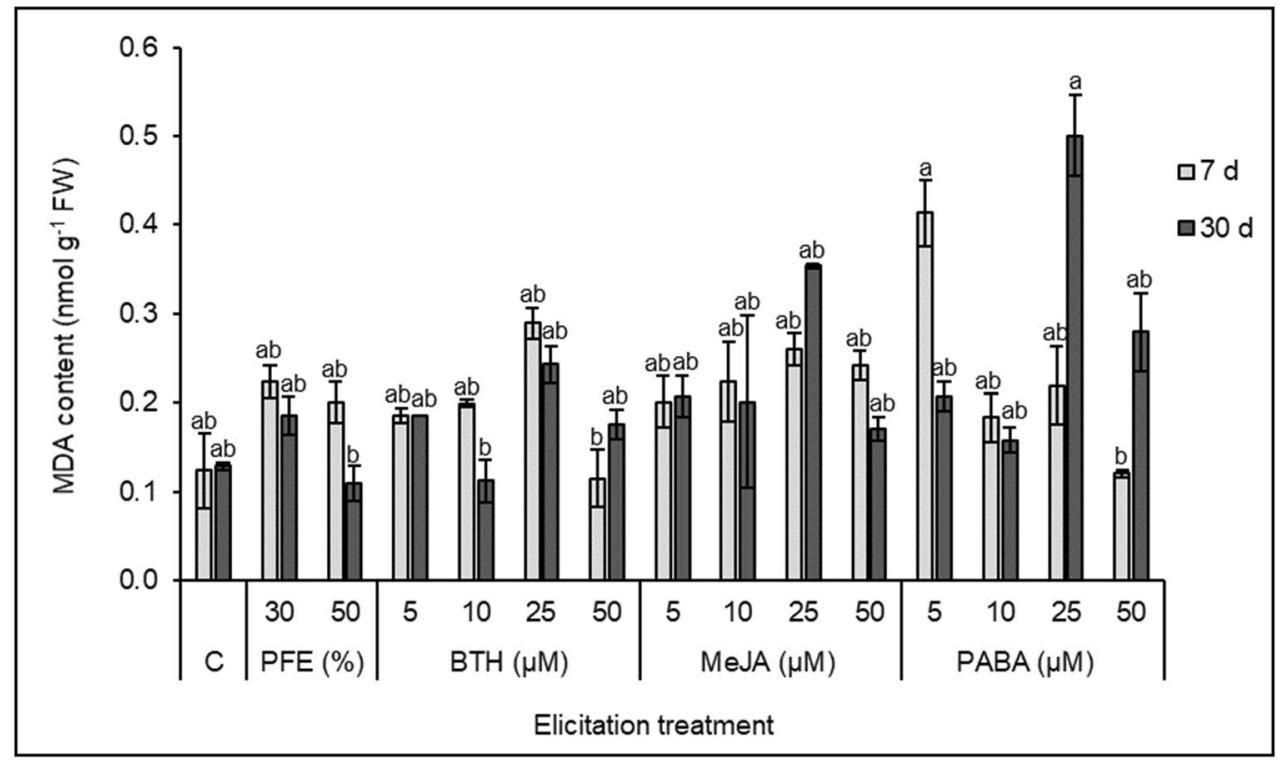

Figure 2. MDA content (nmol g $\left.{ }^{-1} \mathrm{FW}\right)$ in holm oak somatic embryos after 7 and 30 days of control (C) or elicitation treatments with Phytophthora filtered extract (PFE), diluted at 30 or $50 \%$, or benzothiadiazole (BTH), methyl jasmonate (MeJA) or $p$-aminobenzoic acid (PABA) at 5, 10, 25 or $50 \mu \mathrm{M}$. Data are mean \pm SD of three replicates. Within each time, values followed by the same letter were not different according to Kruskal-Wallis test with Bonferroni correction for multiple comparisons.

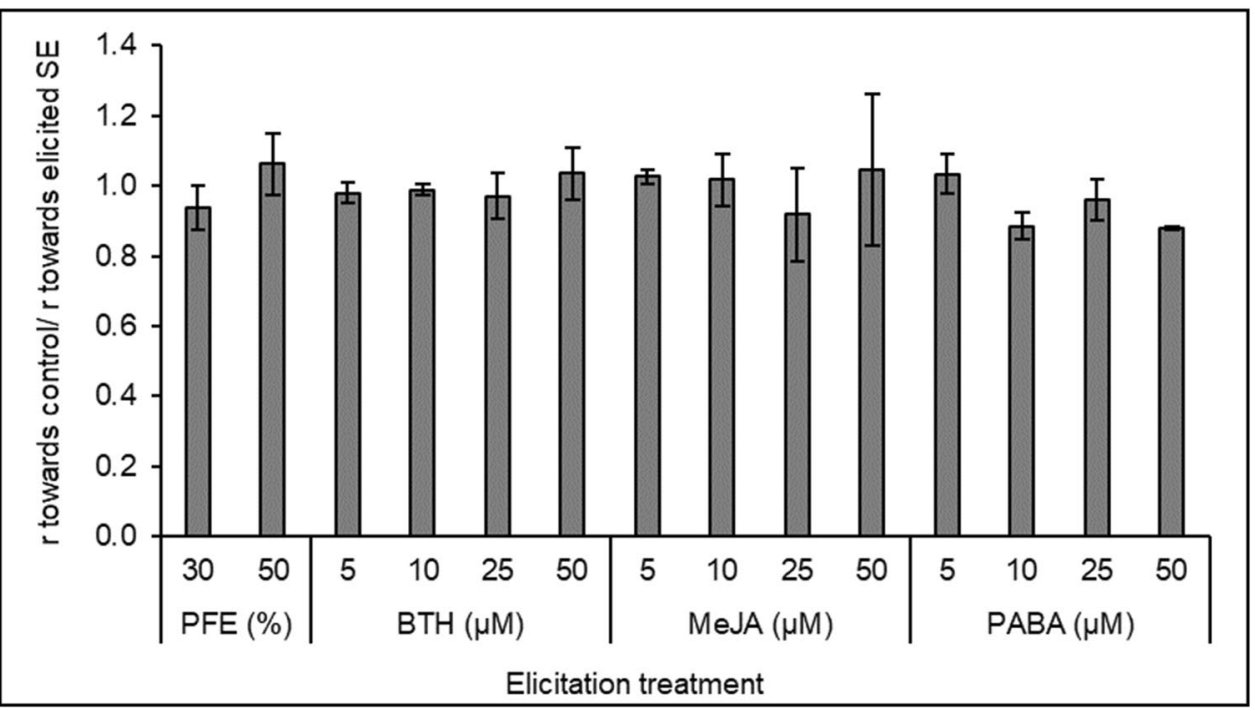

Figure 3. Dual cultures: mean Phytophthora cinnamomi mycelia growth ratios (towards control/elicited) measured after 3 days of challenging control and elicited embryogenic material with active oomycete. Elicitation treatments were performed in triplicate using Phytophthora filtered extract (PFE) diluted at 30 or $50 \%$ or benzothiadiazole (BTH), methyl jasmonate (MeJA) or $p$-aminobenzoic acid (PABA) at 5, 10, 25 or $50 \mu \mathrm{M}$.

shown in Fig. 3, at the end of the experiment (day 3) a significant inhibitory effect of elicited SEs was not detected in these bioassays.

Hydrogen peroxide production in holm oak SEs after Phytophthora cinnamomi dual cultures. Hydrogen peroxide production in control and elicited holm oak SEs was determined after challenging this material with oomycete mycelia in dual culture assays. As shown in Fig. 4, significant differences in $\mathrm{H}_{2} \mathrm{O}_{2}$ production were observed among samples from different elicitation treatments. Higher $\mathrm{H}_{2} \mathrm{O}_{2}$ level in response to oomycete challenge was determined in SEs elicited with $50 \mu \mathrm{M}$ MeJA $\left(7.35 \pm 0.32 \mu \mathrm{g} \mathrm{mL}^{-1}\right)$ or $10 \mu \mathrm{M}$ PABA 


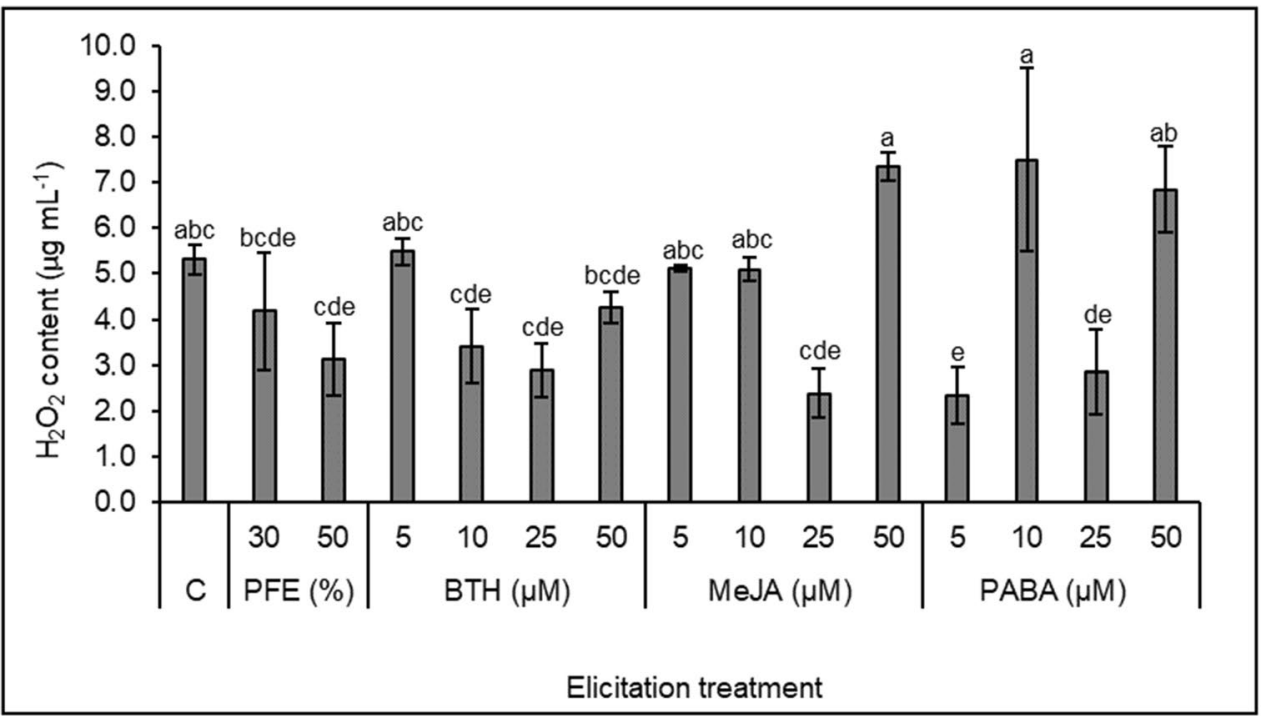

Figure 4. Hydrogen peroxide content $\left(\mu \mathrm{g} \mathrm{mL}^{-1}\right)$ in control $(\mathrm{C})$ and elicited holm oak somatic embryos after dual cultures with Phytophthora cinnamomi. Elicitation treatments tested were Phytophthora filtered extract (PFE) diluted at 30 or $50 \%$, or benzothiadiazole (BTH), methyl jasmonate (MeJA) or $p$-aminobenzoic acid (PABA) at $5,10,25$ or $50 \mu \mathrm{M}$. Values are mean \pm SD of three replicates, and those followed by the same letter were not significantly different according to Tukey-B test.

$\left(7.50 \pm 2.00 \mu \mathrm{g} \mathrm{mL} \mathrm{m}^{-1}\right)$, although values did not differ significantly from that found in non-elicited material. In contrast, $\mathrm{H}_{2} \mathrm{O}_{2}$ production was significantly repressed in holm oak SEs elicited with 5 or $25 \mu \mathrm{M}$ PABA as compared to controls $\left(2.34 \pm 0.61\right.$ and $2.86 \pm 0.92 \mu \mathrm{g} \mathrm{mL}^{-1}$, respectively, vs $\left.5.31 \pm 0.33 \mu \mathrm{g} \mathrm{mL}^{-1}\right)$.

\section{Discussion}

The design of an effective strategy to induce tolerance to P. cinnamomi in holm oak must consider the effect of elicitation treatments on the embryogenic material, to avoid a decrease in somatic embryos proliferation that impede the plant regeneration ${ }^{36}$. In our study, abnormally developed embryos were mainly observed in embryogenic material elicited with high concentrations $(25$ or $50 \mu \mathrm{M})$ of BTH or PABA. Other authors also reported that high concentrations of some elicitors could negatively influence the biologic development of plant material ${ }^{37}$. On the contrary, MeJA application produced a recovery in the differentiation capacity of an embryogenic line of Quercus ilex ${ }^{36}$. Then, possible detrimental effects of the elicitation treatments tested herein were also assessed by determining MDA content of holm oak SEs. MDA production indicates high lipid peroxidation in plant cells ${ }^{38-41}$. In our experiments this compound was detected in higher concentration in SEs from all elicitation treatments, although MDA contents were not significantly different from that of controls. Interestingly, $7 \mathrm{~d}$ after elicitation we observed lower MDA levels in SEs treated with the highest BTH or PABA concentration $(50 \mu \mathrm{M})$, in contrast to the higher MDA content determined in material elicited with $5 \mu \mathrm{M}$ PABA. However, after 30 days we observed a recovery of cell membranes integrity in this material, and also in those elicited with PFE or MeJA at the higher concentrations, while MDA content increased in material elicited with 25 or $50 \mu \mathrm{M}$ PABA or with $50 \mu \mathrm{M}$ BTH. These results suggest a negative effect of PABA-elicitation on cell membrane integrity of holm oak SEs that could be related to the lower embryo development frequencies observed on average in these treatments. Chong et al. ${ }^{42}$ suggested that damages in cell membranes during the first days after elicitation of Morinda elliptica cell cultures with MeJA would trigger the biosynthesis of antioxidant enzymes, therefore inducing a subsequent decrease in MDA.

Experiments using dual cultures have shown that the stimulation or inhibition of mycelium growth in these conditions could give useful information about plant susceptibility ${ }^{43-45}$, and therefore could be used to select efficient elicitation treatments ${ }^{36,42}$. In our study, elicited holm oak somatic embryos did not inhibit Phytophthora cinnamomi mycelium growth in dual culture tests, being the plates with somatic embryos elicited with PFE-50, $50 \mu \mathrm{M}$ BTH, 5,10 or $50 \mu \mathrm{M}$ MeJA and $5 \mu \mathrm{M}$ PABA those showing ratios higher than 1 between growth towards control and growth towards elicited material at the end of the experiment. Treatments with cinnamomin have been reported to inhibit oomycete root colonization in holm oak ${ }^{21}$; foliar applications of a BTH derivate also reduced the incidence of oomycete root infection in several forest ${ }^{28}$; MeJA have been referred to induce resistance in conifers seedlings to a pathogenic oomycete ${ }^{46}$ and pests ${ }^{47-49}$, as well as resistance to pathogens in plants such as arabidopsis ${ }^{50}$, grapevine ${ }^{51}$ or tomato ${ }^{37}$, and in harvested fruits as bayberries ${ }^{52}$ and grapes ${ }^{53,54}$.

Wang et al. ${ }^{54}$ reported that induced resistance to Botrytis cinerea of grape fruits treated with MeJA was tightly associated with increased $\mathrm{H}_{2} \mathrm{O}_{2}$ production in this plant material. This biotic stress response was characterized in holm oak elicited somatic embryos, and we found higher $\mathrm{H}_{2} \mathrm{O}_{2}$ contents in samples elicited with $50 \mu \mathrm{M}$ MeJA 


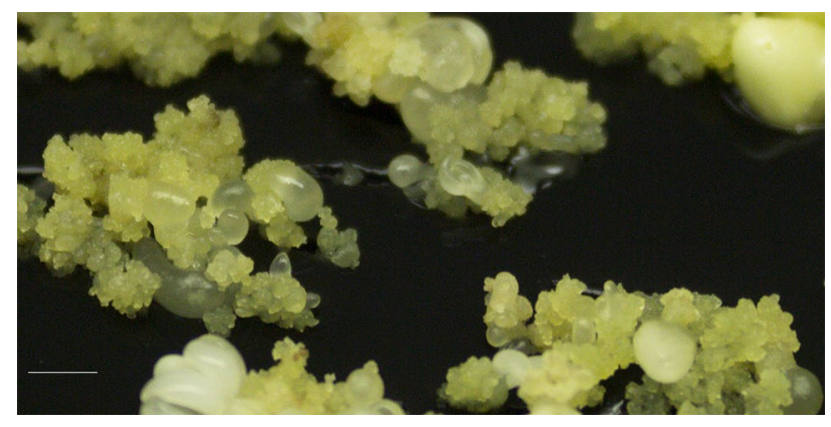

Figure 5. Holm oak embryogenic line Ha13 showing SEs at different developmental stages. Bar $1 \mathrm{~cm}$.

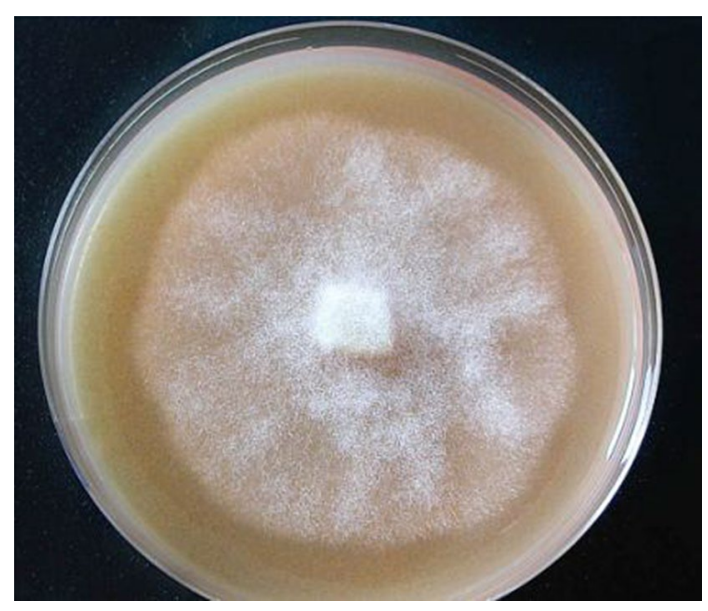

Figure 6. Phytophthora cinnamomi 1630 strain after 10 days of transference to fresh PDA medium.

and 10 or $50 \mu \mathrm{M}$ PABA $(p>0.05)$, therefore indicating a better activation of defense mechanism in these plant materials.

In spite of significant differences in all parameters were not found, an overview of our results concerning SE growth and development, MDA production, inhibition of mycelia growth and $\mathrm{H}_{2} \mathrm{O}_{2}$ production suggest that in our conditions $50 \mu \mathrm{M}$ MeJA seems to be the most adequate elicitation treatment in holm oak embryogenic material. These results contribute to the scarce available information about elicitation of somatic embryogenic material of Quercus species.

\section{Material and methods}

Plant and oomycete material. The experiments were undertaken with the embryogenic holm oak (Quercus ilex L.) line Ha13. This line was obtained from male catkins of a 50-100-year-old holm oak located in La Hunde mountain (Ayora, Valencia, Spain) as described in $^{16}$ and has being maintained in vitro by monthly subcultures on proliferation $\mathrm{MS}^{55}$ medium supplemented with $20 \mu \mathrm{M}$ silver thiosulfate and $4 \mathrm{~g} \mathrm{~L}^{-1}$ activated charcoal (named after MS/STS/AC medium as described in ${ }^{56}$ ). On this medium, Ha13 line produces secondary embryogenesis and somatic embryos (SEs) at different developmental stages (Fig. 5) from which material consisting of embryogenic calli and globular SEs was employed for elicitation experiments.

Phytophthora cinnamomi strain 1630 was kindly provided by Paloma Abad (group Phytopathogenic fungi, Instituto Agroforestal Mediterráneo-Universidad Politécnica de Valencia, Spain) and was maintained in PDA medium (Potato Dextrose Agar, Pronadisa) by subculturing mycelium pieces of $0.5 \mathrm{~cm}^{2}$ to fresh medium every 15 days (Fig. 6).

Elicitation assays. Elicitation assays were performed with either filtered extract of Phytophthora cinnamomi 1630 strain (Fig. 6) diluted at 30 or 50\% v/v (named after PFE-30 and PFE-50, respectively), or the chemical elicitors methyl jasmonate (MeJA), benzothiadiazole (BTH) and p-aminobenzoic acid (PABA) at 5, 10, 25 and $50 \mu \mathrm{M}$.

To prepare the oomycete extract, flasks containing $40 \mathrm{~mL}$ liquid ESM medium (Elicitin Secretion Medium ${ }^{57}$ ) were inoculated with eight $0.5 \mathrm{~cm}^{2} P$. cinnamomi mycelium cuts from outer edge of 1630 strain $P$. cinnamomi mycelium that had been growing in PDA medium, at $25^{\circ} \mathrm{C}$ and darkness during 10 days. ESM medium consisted of $500 \mathrm{mg} \mathrm{L}^{-1} \mathrm{KH}_{2} \mathrm{PO}_{4}, 250 \mathrm{mg} \mathrm{L}^{-1} \mathrm{MgSO}_{4} \cdot 7 \mathrm{H}_{2} \mathrm{O}, 1,000 \mathrm{mg} \mathrm{L}^{-1}$ asparagine, $1 \mathrm{mg} \mathrm{L}^{-1}$ thiamine, $20 \mathrm{mg} \mathrm{L}^{-1}$ glucose 


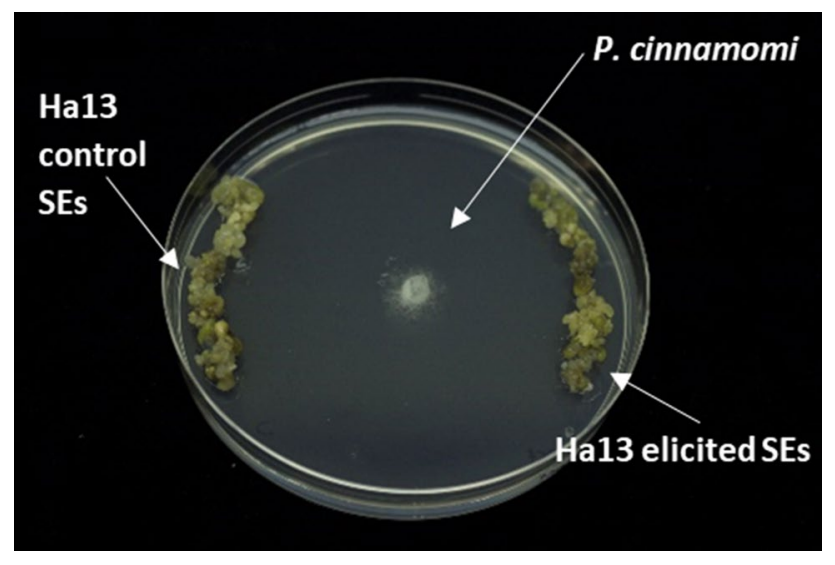

Figure 7. Establishment of dual cultures with Phytophthora cinnamomi (middle) and holm oak embryogenic line Ha13 control (left) and elicited (right).

and $500 \mathrm{mg} \mathrm{L}^{-1}$ yeast extract. The oomycete cultures were maintained at $25{ }^{\circ} \mathrm{C}$, in darkness and agitation at $50 \mathrm{rpm}$ for 5 days. After this period, the cultures were collected by filtration using Büchner funnels and $90 \mathrm{~mm}$ Whatman filter paper; subsequently, the liquid extracts were sterilized through $0.22 \mu \mathrm{m}$ Whatman filters ${ }^{58}$; finally, the sterile extract was diluted at 30 or $50 \% \mathrm{v} / \mathrm{v}$ in ESM medium.

For elicitation, the embryogenic line containing SE at the globular stage was cultured for 3 days in $40 \mathrm{~mL}$ ESM medium supplemented with the above-mentioned elicitors in agitation at $100 \mathrm{rpm}, 25^{\circ} \mathrm{C}$ and darkness; after this period, the embryos were recovered on Whatman filter paper, using Büchner funnels, and transferred to MS/ STS/AC proliferation medium. The effect of elicitation treatments on holm oak embryogenesis was determined as SE growth (fresh weight increase) and SE development (percentage of well-formed immature cotyledonary SEs) 60 days after elicitation in triplicate.

Determination of malondialdehyde. To assess the potential damage of elicitors on cell membrane integrity, we determined malondialdehyde (MDA) concentration in control and elicited embryos 7 and 30 days after elicitation, as described $\mathrm{in}^{59}$. To this end, $0.1 \mathrm{~g}$ of embryogenic material was homogenized in $1 \mathrm{~mL}$ of $50 \mathrm{mM}$ extraction solution $\left(0.07 \% \mathrm{NaH}_{2} \mathrm{PO}_{4} \cdot 2 \mathrm{H}_{2} \mathrm{O}\right.$ and $\left.1.6 \% \mathrm{Na}_{2} \mathrm{HPO}_{4} \cdot 12 \mathrm{H}_{2} \mathrm{O}\right)$ and centrifuged at $13,000 \mathrm{rpm}$ for $25 \mathrm{~min}$ at $4{ }^{\circ} \mathrm{C}$. After that, $200 \mu \mathrm{L}$ of the supernatant were added to $800 \mu \mathrm{L}$ of a solution containing $20 \%$ trichloroacetic acid (TCA) and 0.5\% thiobarbituric acid (TBA) (both from Sigma-Aldrich, USA). The mixture was heated at $95^{\circ} \mathrm{C}$ for $30 \mathrm{~min}$, quickly cooled in an ice bath and centrifuged at 13,000 rpm for $10 \mathrm{~min}$. The absorbance of the supernatant was read at 532 and at $600 \mathrm{~nm}$ in an Eppendorf BioSpectrometer. The value for the non-specific absorption at $600 \mathrm{~nm}$ was subtracted from the reading at $532 \mathrm{~nm}$. MDA concentration was calculated using the MDA extinction coefficient of $155 \mathrm{mM}^{-1} \mathrm{~cm}^{-1}$ according to ${ }^{60}$. Each treatment was tested in triplicate.

Growth of Phytophthora cinnamomi in dual cultures with elicited holm oak SEs. Globular SEs $(0.3 \mathrm{~g})$ from elicited and control material maintained in MS/STS/AC medium for 90 days were incubated in the presence of $P$. cinnamomi mycelium $\left(0.5 \mathrm{~cm}^{2}\right)$ on $90 \mathrm{~mm}$ petri dishes containing $\mathrm{SH}$ medium ${ }^{61}$ without plant growth regulators. The section of $P$. cinnamomi mycelium was placed in the middle of the dish (Fig. 7) and the ratio of mycelium growth towards the control and the elicited material was evaluated daily until oomycete hyphae reached SEs (3 days). Therefore, mycelia growth ratios $>1$ indicate that the oomycete mycelium spread faster to control samples than to elicited material. Material from each elicitation treatment was tested in triplicate.

Determination of hydrogen peroxide in plant material during dual cultures. As a measure of primary defense response to oomycete's infection, we determined hydrogen peroxide $\left(\mathrm{H}_{2} \mathrm{O}_{2}\right)$ formation in both control and elicited SEs after 3 days of dual culture with P. cinnamomi mycelium, according to ${ }^{42}$. Briefly, $0.1 \mathrm{~g}$ of elicited or control and infected SEs was homogenized in $1 \mathrm{~mL} 0.1 \%(\mathrm{w} / \mathrm{v})$ TCA. The homogenate was centrifuged at $13,000 \mathrm{rpm}$ at $4{ }^{\circ} \mathrm{C}$ for $15 \mathrm{~min}$ and $250 \mu \mathrm{L}$ of the supernatant was added to $250 \mu \mathrm{L} 10 \mathrm{mM}$ potassium phosphate buffer ( $\mathrm{pH} 7.0$ ) and $500 \mu \mathrm{L} 1 \mathrm{M}$ potassium iodide. Absorbance of each sample was read at $390 \mathrm{~nm}$ and treatments were tested in triplicate.

Statistical analysis. Data were analyzed by one-way analysis of variance (ANOVA), and are presented as mean \pm standard deviation of three independent replications. When appropriate, treatment means were separated using Tukey's HSD (honestly significant difference ${ }^{62}$ ). Data that not followed a normal distribution were analyzed by the Kruskal-Wallis one-way non-parametric test (k independent samples) or U-Mann-Whitney test ( 2 independent samples). The arcsine transformation was applied to percentage data prior to analysis. All statistical analyses were performed using SPSS for Windows, version 26 (SPSS Inc., Chicago, IL, USA). 
Received: 19 June 2020; Accepted: 7 August 2020

Published online: 16 September 2020

\section{References}

1. ValeroGalván, J. et al. Population variability based on the morphometry and chemical composition of the acorn in Holm oak (Quercus ilex subsp. ballota [Desf.] Samp.). Eur. J. For. Res. 131, 893-904 (2012).

2. Mauri, P. V. \& Manzanera, J. A. Induction, maturation and germination of holm oak (Quercus ilex L.) somatic embryos. Plant. Cell. Tiss. Org. Cult. 74, 229-235 (2003).

3. Pinto-Correia, T., Ribeiro, N. \& Sá-Sousa, P. Introducing the montado, the cork and holm oak agroforestry system of Southern Portugal. Agrofor. Syst. 82, 99-104 (2011).

4. Marañón, T., Ibáñez, B., Anaya-Romero, M., Muñoz-Rojas, M. \& Pérez-Ramos, I. Oak trees and woodlands providing ecosystem services in Southern Spain. In Book: Trees Beyond the Wood. An Exploration of Concepts of Woods, Forests and Trees (eds Rotherham, I. D. et al.) 369-378 (Wildtrack Publishing, Sheffield, 2012).

5. Mauri, P. V. \& Manzanera, J. A. Effect of abscisic acid and stratification on somatic embryo maturation and germination of holm oak (Quercus ilex L.). Vitro Cell. Dev. Biol. Plant. 40, 495-498 (2004).

6. Gea-Izquierdo, G., Cañellas, I. \& Montero, G. Acorn production in Spanish holm oak woodlands. Investig. Agrar. Sist. Recur. For. 15, 339 (2006).

7. Suz, L. M., Martín, M. P., Oliach, D., Fischer, C. R. \& Colinas, C. Mycelial abundance and other factors related to truffle productivity in Tuber melanosporum-Quercus ilex orchards. FEMS Microbiol. Lett. 285, 72-78 (2008).

8. Serrada, R. \& San Miguel Ayanz, A. Selvicultura en dehesas. In Compend Selvicultura Apl en España (eds Serrada, R. et al.) 861-876 (INIA-Fundación Conde del Valle de Salazar, Madrid, 2008).

9. Brasier, C. M. Phytophthora cinnamomi and oak decline in southern Europe. Environmental constraints including climate change. Ann. Sci. For. 53, 347-358 (1996).

10. Torres-Álvarez, E., Rodríguez-Molina, M. C., Torres-Vila, L. M. \& Suárez de La Cámara, M. A. ¿Qué papel juega el hongo Phytophthora cinnamomi en el desarrollo de la regeneración natural y las repoblaciones de encina y alcornoque?. BolInf. CIDEU. 1, 53-63 (2006).

11. Camilo-Alves, C. S. P., da Clara, M. I. E. \& de Almeida Ribeiro, N. M. C. Decline of Mediterranean oak trees and its association with Phytophthora cinnamomi: A review. Eur. J. For. Res. 132, 411-432 (2013).

12. Corcobado, T., Cubera, E., Juarez, E., Moreno, G. \& Solla, A. Drought events determine performance of Quercus ilex seedlings and increase their susceptibility to Phytophthora cinnamomi. Agric. For. Meteorol. 192-193, 1-8 (2014).

13. Nawrot-Chorabik, K. \& Pietrzykowski, M. Ecophysiological aspects of in vitro biotechnological studies using somatic embryogenesis of callus tissue toward protecting forest ecosystems. J. For. Res. 30, 1159-1166 (2019).

14. Martínez, M. T. et al. Holm oak somatic embryogenesis: Current status and future perspectives. Front. Plant Sci. 10, 239. https:// doi.org/10.3389/fpls.2019.00239 (2019).

15. Martínez, M. T. et al. Micropropagation of mature Quercus ilex L. trees by axillary budding. Plant Cell Tiss. Organ Cult. 131, 499-512 (2017).

16. Blasco, M. et al. Somatic embryogenesis in holm oak male catkins. Plant. Growth. Regul. 71, 261-270 (2013).

17. Barra-Jiménez, A. et al. Cloning mature holm oak trees by somatic embryogenesis. Trees 28, 657-667 (2014)

18. Martínez, M. T. et al. Propagation of mature Quercus ilex L. (holm oak) trees by somatic embryogenesis. Plant Cell Tiss. Organ Cult. 131, 321-333 (2017).

19. Wang, Y., Tyler, B. M. \& Wang, Y. Defense and counterdefense during plant-pathogenic oomycete infection. Annu. Rev. Microbiol. 73, 667-696 (2019).

20. Walters, D., Walsh, D., Newton, A. \& Lyon, G. Induced resistance for plant disease control: Maximizing the efficacy of resistance elicitors. Phytopathology. 95, 1368-1373 (2005).

21. Ebadzad, G., Medeira, C., Maia, I., Martins, J. \& Cravador, A. Induction of defence responses by cinnamomins against Phytophthora cinnamomi in Quercus suber and Quercus ilex subs. rotundifolia. Eur. J. Plant. Pathol. 143, 705-723 (2015).

22. Llorens, E., García-Agustín, P. \& Lapeña, L. Advances in induced resistance by natural compounds: Towards new options for woody crop protection. Sci. Agric. 74, 90-100 (2017).

23. Li, T., Huang, Y., Xu, Z. S., Wang, F. \& Xiong, A. S. Salicylic acid-induced differential resistance to the Tomato yellow leaf curl virus among resistant and susceptible tomato cultivars. BMC Plant. Biol. 19, 1-14 (2019).

24. Conrath, U., Beckers, G. J. M., Langenbach, C. J. G. \& Jaskiewicz, M. R. Priming for enhanced defense. Annu. Rev. Phytopathol. 53, 97-119 (2015).

25. Martín, J. A., Solla, A., Coimbra, M. A. \& Gil, L. Metabolic fingerprinting allows discrimination between Ulmus pumila and $U$. minor, and between U. minor clones of different susceptibility to Dutch elm disease. For. Pathol. 38, 244-256 (2008).

26. Martín, J. A., Solla, A., Witzell, J., Gil, L. \& García-Vallejo, M. C. Antifungal effect and reduction of Ulmus minor symptoms to Ophiostoma novo-ulmi by carvacrol and salicylic acid. Eur. J. Plant. Pathol. 127, 21-32 (2010).

27. Reglinski, T., Stavely, F. J. L. \& Taylor, J. T. Induction of phenylalanine ammonia lyase activity and control of Sphaeropsis sapinea infection in Pinus radiata by 5-chlorosalicylic acid. Eur. J. For. Pathol. 28, 153-158 (1998).

28. Ali, Z., Smith, I. \& Guest, D. I. Combinations of potassium phosphonate and Bion (acibenzolar-S-methyl) reduce root infection and dieback of Pinus radiata, Banksia integrifolia and Isopogon cuneatus caused by Phytophthora cinnamomi. Australas. Plant. Pathol. 29, 59-63 (2000).

29. Mauch-Mani, B., Baccelli, I., Luna, E. \& Flors, V. Defense priming: An adaptive part of induced resistance. Annu. Rev. Plant. Biol. 68, 485-512 (2017).

30. Richards, E. J. Inherited epigenetic variation-revisiting soft inheritance. Nat. Rev. Genet. 7, 395-401 (2006).

31. Holeski, L. M., Jander, G. \& Agrawal, A. A. Transgenerational defense induction and epigenetic inheritance in plants. Trends. Ecol. Evol. 27, 618-626 (2012).

32. Vivas, M., Zas, R., Sampedro, L. \& Solla, A. Environmental maternal effects mediate the resistance of maritime pine to biotic stress. PLoS One. 8, 20. https://doi.org/10.1371/journal.pone.0070148 (2013).

33. Luna, E., Bruce, T. J. A., Roberts, M. R., Flors, V. \& Ton, J. Next-generation systemic acquired resistance. Plant. Physiol. 158, 844-853 (2012).

34. Slaughter, A. et al. Descendants of primed Arabidopsis plants exhibit resistance to biotic stress. Plant. Physiol. 158, 835-843 (2012).

35. Camisón, Á, Martín, M. Á, Oliva, J., Elfstrand, M. \& Solla, A. Increased tolerance to Phytophthora cinnamomi in offspring of inkdiseased chestnut (Castanea sativa Miller) trees. Ann. For. Sci. 76, 20. https://doi.org/10.1007/s13595-019-0898-8 (2019).

36. Ruiz-Galea, M., Celestino, C. \& Toribio, M. Evaluación de la induccion de respuestas de defensa a Phytopthora cinnamomi Rands. En embriones somáticos de encina. Congr. For. Español. Plasencia-Cáceres Extremadura 2017, 26-30 (2017).

37. Kepczyńska, E. \& Król, P. The phytohormone methyl jasmonate as an activator of induced resistance against the necrotroph Alternaria porri f. sp. solani in tomato plants. J. Plant. Interact. 7, 307-315 (2012).

38. Draper, H. H. \& Hadley, M. Malondialdehyde determination as index of lipid peroxidation. Methods. Enzymol. 186B, 421-431 (1990) 
39. Esterbauer, H. \& Cheeseman, K. H. Determination of aldehydic lipid peroxidation products: Malonaldehyde and 4-hydroxynonenal. Methods. Enzymol. 186, 407-421 (1990).

40. Arbona, V., Hossain, Z., López-Climent, M. F., Pérez-Clemente, R. M. \& Gómez-Cadenas, A. Antioxidant enzymatic activity is linked to waterlogging stress tolerance in citrus. Physiol. Plant. 132, 452-466 (2008).

41. Ayala, A., Muñoz, M. F. \& Argüelles, S. Lipid peroxidation: Production, metabolism, and signalling mechanisms of malondialdehyde and 4-hydroxy-2-nonenal. Oxid. Med. Cell. Longev. https://doi.org/10.1155/2014/360438 (2014).

42. Chong, T. M., Abdullah, M. A., Fadzillah, N. M., Lai, O. M. \& Lajis, N. H. Jasmonic acid elicitation of anthraquinones with some associated enzymic and non-enzymic antioxidant responses in Morinda elliptica. Enzyme. Microb. Technol. 36, 469-477 (2005).

43. Nawrot-Chorabik, K. The use of interactions in dual cultures in vitro to evaluate the pathogenicity of fungi and susceptibility of host plant genotypes. In Environmental Biotechnology-New Approaches and Prospective Applications (ed. Petre, M. R.) 287-301 (Intech Open Science Publisher, Rejika, 2013).

44. Nawrot-Chorabik, K. Interactions between embryogenic callus of Abies alba and Heterobasidion spp. in dual cultures. Biol. Plant. 58, 363-369 (2014).

45. Nawrot-Chorabik, K., Grad, B. \& Kowalski, T. Interactions between callus cultures of Pinus sylvestris and pine fungi with different trophic properties. For. Pathol. 46, 179-186 (2016).

46. Kozlowski, G., Buchala, A. \& Métraux, J. P. Methyl jasmonate protects Norway spruce [Picea abies (L.) Karst.] seedlings against Pythium ultimum Trow. Physiol. Mol. Plant. Pathol. 55, 53-58 (1999).

47. Heijari, J. et al. Application of methyl jasmonate reduces growth but increases chemical defence and resistance against Hylobius abietis in Scots pine seedlings. Entomol. Exp. Appl. 115, 117-124 (2005).

48. Holopainen, J. K., Heijari, J., Nerg, A. M., Vuorinen, M. \& Kainulainen, P. Potential for the use of exogenous chemical elicitors in disease and insect pest management of conifer seedling production. Open. For. Sci. J. 2, 17-24 (2009).

49. Zas, R. et al. Exploiting jasmonate-induced responses for field protection of conifer seedlings against a major forest pest, Hylobius abietis. For. Ecol. Manag. 313, 212-223 (2014).

50. Thomma, B. P. H. J., Eggermont, K., Broekaert, W. F. \& Cammue, B. P. A. Disease development of several fungi on Arabidopsis can be reduced by treatment with methyl jasmonate. Plant. Physiol. Biochem. 38, 421-427 (2000).

51. Belhadj, A. et al. Methyl jasmonate induces defense responses in grapevine and triggers protection against Erysiphe necator. J. Agric. Food. Chem. 54, 9119-9125 (2006).

52. Wang, K. et al. Methyl jasmonate induces resistance against Penicillium citrinum in Chinese bayberry by priming of defense responses. Postharvest. Biol. Technol. 98, 90-97 (2014).

53. Jiang, L. et al. Methyl jasmonate primes defense responses against Botrytis cinerea and reduces disease development in harvested table grapes. Sci. Hortic. 192, 218-223 (2015).

54. Wang, K., Liao, Y., Kan, J., Han, L. \& Zheng, Y. Response of direct or priming defense against Botrytis cinerea to methyl jasmonate treatment at different concentrations in grape berries. Int. J. Food. Microbiol. 194, 32-39 (2015).

55. Murashige, T. \& Skoog, F. A revised medium for rapid growth and bio assays with tobacco tissue cultures. Physiol. Planta. 15, 473-497 (1962).

56. Martínez, M. T., Vieitez, A. M. \& Corredoira, E. Improved secondary embryo production in Quercus alba and Q. rubra by activated charcoal, silver thiosulphate and sucrose: Influence of embryogenic explant used for subculture. Plant. Cell. Tiss. Org. Cult. 121, $531-546$ (2015).

57. Horta, M., Sousa, N., Coelho, A. C., Neves, D. \& Cravador, A. In vitro and in vivo quantification of elicitin expression in Phytophthora cinnamomi. Physiol. Mol. Plant. Pathol. 73, 48-57 (2008).

58. Ganesan, M. \& Jayabalan, N. Isolation of disease-tolerant cotton (Gossypium hirsutum L. cv. SVPR 2) plants by screening somatic embryos with fungal culture filtrate. Plant. Cell. Tiss. Org. Cult. 87, 273-284 (2006).

59. Cervilla, L. M., Blasco, B., Ríos, J. J., Romero, L. \& Ruiz, J. M. Oxidative stress and antioxidants in tomato (Solanum lycopersicum) plants subjected to boron toxicity. Ann. Bot. 100, 747-756 (2007).

60. Heath, R. L. \& Packer, L. Photoperoxidation in isolated chloroplasts: I. Kinetics and stoichiometry of fatty acid peroxidation. Arch. Biochem. Biophys. 125, 189-198 (1968).

61. Schenk, R. V. \& Hildebrandt, A. C. Medium and techniques for induction and growth of Monocotyledonous and Dicotyledonous plant cell cultures. Can. J. Bot. 50, 199-204 (1972).

62. Tukey, J. W. Some selected quick and easy methods of statistical analysis. Trans. NY Acad. Sci. 16, 88-97 (1953).

\section{Acknowledgements}

Authors would like to thank Dra. Abad and her research group (Phytopathogenic fungi, Instituto Agroforestal Mediterráneo-Universidad Politécnica de Valencia) for providing the strain used in this study (1630 Phytophthora cinnamomi) and to Álex Alborch for the technical assistance. This work was supported by the research projects financed by MICINN and the EU (AGL2013-47400-C4-04-R and AGL2016-76143-C4-01-R) and by a predoctoral contract to M.M (BES-2014-069171).

\section{Author contributions}

M.M., L.P. and A.G performed the experiments; M.M., E.S., J.S and I.A wrote the manuscript text; M.M; E.S and I.A performed the statistics; E.S., J.S. and I.A. design the project. All authors reviewed the manuscript.

\section{Competing interests}

The authors declare no competing interests.

\section{Additional information}

Correspondence and requests for materials should be addressed to I.A.

Reprints and permissions information is available at www.nature.com/reprints.

Publisher's note Springer Nature remains neutral with regard to jurisdictional claims in published maps and institutional affiliations. 
(c) (i) Open Access This article is licensed under a Creative Commons Attribution 4.0 International cc) License, which permits use, sharing, adaptation, distribution and reproduction in any medium or format, as long as you give appropriate credit to the original author(s) and the source, provide a link to the Creative Commons licence, and indicate if changes were made. The images or other third party material in this article are included in the article's Creative Commons licence, unless indicated otherwise in a credit line to the material. If material is not included in the article's Creative Commons licence and your intended use is not permitted by statutory regulation or exceeds the permitted use, you will need to obtain permission directly from the copyright holder. To view a copy of this licence, visit http://creativecommons.org/licenses/by/4.0/.

(C) The Author(s) 2020 